that are toxic and/or difficult to handle. The branched polymer mPEG 2 lis was coupled to IFN $\alpha-2 a$ and purified using chromatographic procedures. The pure conjugate was compared with an available pegylated product $\mathrm{mPEG}_{2}(40 \mathrm{kDa})-$ IFN $\alpha-2 \mathrm{a}$. SE-HPLC, SDS-PAGE procedures and antiviral activity and antiproliferative in vitro assays revealed that both molecules were not different. The pharmacokinetic profiles were encouraging.

Independently, we synthesized a new linear PEG derivative activated as carbonyl imidazolium iodide (mPEG- $\mid \mathrm{m}^{+} \mathrm{I}^{-}$), and this derivative was successfully employed in the pegylation of IFN $\alpha-2 b$, yielding $32 \%$ of the monopegylated compound. CommerciaIly available PEG (12 kDa) - IFN $\alpha-2 b$, was used to make comparisons with the molecule produced in the laboratory, after being purified. We concluded that polymer MPEG$\mathrm{Im}^{+} \mathrm{I}^{-}$may be used as a PEG derivative to biomolecule conjugation, having a comparable reactivity with other activated PEGs frequently used in the field of pegylation.

\title{
Estudios de las especies americanas del género Cenchrus L (Poaceae: Panicoideae: Paniceae)
}

\section{Hugo Francisco Gutiérrez}

hgutierr@fca.unl.edu.ar

Dr. Osvaldo Morrone

Dr. José F. Pensiero

Cátedra de Botánica Sistemática Agronómica - Pabellón de Estudios botánicos y Ecológicos

Facultad de Ciencias Agrarias

Universidad Nacional del Litoral

Fecha de defensa: 19/03/2013

\section{Resumen}

Recientes estudios filogenéticos aportaron evidencia sobre la monofilia de los géneros Cenchrus, Pennisetum y Odontelytrum, proponiendo su unificación y transferencia a Cenchrus, el cual tiene prioridad. Hasta el presente, no hay antecedentes que consideren su tratamiento taxonómico en forma conjunta. El propósito de este trabajo fue realizar la revisión taxonómica de las especies americanas del género Cenchrus s.l. y, probar la utilidad de los caracteres morfológicos evaluados en análisis filogenéticos. Como este estudio se circunscribe al continente americano, el género monotípico Odontelytrum, originario de África, fue excluido del análisis. Para llevar a cabo la revisión taxonómica, se estudiaron ejemplares de herbario provenientes de instituciones de Argentina y del extranjero. Previo al tratamiento taxonómico se analizó la diversidad morfológica en las estructuras vegetativas y reproductivas de las especies para identificar caracteres diagnósticos que faciliten su posterior determinación, reconociéndose 7 grupos de especies. El tratamiento taxonómico permitió reconocer 41 especies, incluidas en 7 categorías infragenéricas (6 secciones y 2 subsecciones). Se proporcionan claves para diferenciar o reconocer los géneros afines, las secciones propuestas y los taxones que habitan en América. Además se presentan descripciones detalladas de las especies, ilustraciones de los caracteres de importancia 
taxonómica, sinonimia actualizada y lectotipificaciones cuando fue necesario. El análisis filogenético, realizado bajo el principio de la máxima parsimonia, reveló que Cenchrus constituye un grupo monofilético, definido por la presencia de setas estériles que caen junto con las espiguillas, una vez alcanzada la madurez de las mismas. Futuros estudios incorporando caracteres moleculares permitirán ampliar la información existente y lograr una sólida hipótesis filogenética del grupo.

\section{Studies of the American species}

of the genus Cenchrus $L$ (Poaceae:

Panicoideae: Paniceae)

\section{Summary}

Recent phylogenetic studies provided evidence on the monophyly of the genera Cenchrus, Pennisetum and Odontelytrum proposing unification and transfer to the genus Cenchrus, which has priority. To date, there is no history to consider their taxonomic treatment together. The purpose of this study was to perform a taxonomic revision of the American species of the genus Cenchrus s.l. and test the utility of morphological characters in phylogenetic analyzes evalua- ted. As this study is limited to the American Continent, the Odontelytrum monotypic genus, native to Africa, was excluded from the analysis. For taxonomic revision, herbarium specimens were studied from institutions of Argentina and other countries. Prior to taxonomic treatment was analyzed morphological diversity in vegetative and reproductive structures of the species to identify diagnostic features that facilitate their subsequent determination, recognizing seven groups of species. The taxonomic treatment identified 41 species included in 7 infrageneric categories (6 sections and 2 subsections). Keys to recognize the related genera, the proposed Sections and all species that grow in America are given. In addition, are shown detailed descriptions of the species, illustrations of the characters of taxonomic importance, synonymy and lectotypifications. Phylogenetic analysis, carried out under the principle of maximum parsimony, revealed that Cenchrus constitutes a monophyletic group, defined by the presence of bristles falling with the spikelets, after reaching maturity. Future studies incorporating molecular characteristics allow expand existing information and to obtain a robust phylogenetic hypothesis of the group.

\section{Construcción, diseño, análisis y puesta en funcionamiento de un foto-bio-reactor; modelado del campo radiante; de los fenómenos de transferencia y de la cinética de crecimiento de algas microscópicas de interés tecnológico}

\author{
Josué Miguel Heinrich \\ heinrichmiguel@hotmail.com \\ Horacio Antonio Irazoqui \\ GiiB - Grupo de Innonación en Bioprocesos
}

Cátedra de Operaciones y Procesos Biotecnológicos. FBCB - UNL

Grupo de Operaciones y Procesos Biotecnológicos. INTEC-CONICET y UNL 